\title{
GASTRO-INTESTINAL STUDIES. VII. THE EXCRETION OF XYLOSE IN PERNICIOUS ANEMIA
}

\author{
By O. M. HELMER AND PAUL J. FOUTS \\ (From the Lilly Laboratory for Clinical Research, Indianapolis City Hospital, and the \\ Department of Medicine, Indiana University School of Medicine, Indianapolis)
}

(Received for publication November 30, 1936)

Since the advent of liver therapy in the treatment of pernicious anemia it has been known that some patients require greater amounts of potent material than others. Beebe and Lewis (1), and Fouts and Zerfas (2) have shown that patients with a higher incidence of complications, arteriosclerosis, and moderate to advanced involvement of the central nervous system, require on the average a greater daily amount of the active principle in the liver to keep the blood and color index near normal than do those not having these complications. The demonstration by Gänsslen (3) and by Castle and Taylor (4), and the subsequent universal verification of their findings, that liver extract administered parenterally was many times more potent than liver extract given by mouth, led to the general acceptance of the theory that failure in absorption of the active principle from the gastro-intestinal tract accounts in the main for increases in the requirement of liver extract. Heath and Fullerton (5) have studied the rate of absorption of iodine and glycine in an attempt to develop a test for absorption. They concluded that the delay in appearance of iodine in saliva after the ingestion of 0.25 gram of potassium iodide is probably a rough measure of the absorptive ability of the upper small intestine. The appearance time was delayed in 7 of 14 patients who had pernicious anemia. They also concluded that the amino-acid nitrogen content of the blood following the ingestion of 25 grams of glycine gave no useful information regarding the rate of absorption from the gastro-intestinal tract. We, likewise, gained no worthwhile information from the determination of blood aminoacid nitrogen following the oral administration of large amounts of liver extract. Following this failure, we studied the excretion of orally administered xylose, since a consideration of its physical and biochemical properties made it appear that xylose would be a useful substance for determining the absorptive ability of the intestinal tract. This sugar is not metabolized (6). It apparently passes through the liver unchanged (7), and is eliminated from the body by the kidney $(7,8)$. It is not readsorbed by the renal tubules (9) and can be recovered with accuracy in the urine and the blood. Because of these properties, the excretion of xylose has likewise been used as an index of kidney function $(7,8)$.

Although Keith, Power, and Peterson (10) found no difference in xylose clearances in two normal individuals when the xylose was administered by mouth and when administered by vein, we felt that changes in absorption from the gastro-intestinal tract might influence the excretion of orally administered xylose. It seemed reasonable to assume that any marked deviation of the excretion of xylose from that anticipated by the study of the kidney function would be due to changes in the absorption from the gastrointestinal tract.

Fishberg (11) has shown that xylose injected into the blood stream disappears at a rate proportionate to the actual momentary concentration of nonfermentable reducing substances in the blood. In addition, Fishberg and Friedfeld $(7,12)$ have shown that following the oral administration of xylose to patients who had normal kidney function, the curve of nonfermentable reducing substances in the blood approaches its normal value after 5 hours, while, in patients with impaired renal function, the curve of nonfermentable reducing substance continues upward, resulting in a definite retention of xylose in the blood at the end of 5 hours. Therefore, in a number of the patients, blood xylose curves were determined in addition to urine xylose. It was assumed that some additional information on absorption might be gained from comparison of the excretion in the urine and the retention in the blood even in cases with poor renal function. Patients having low excretion and low blood xylose curves would 
have to be considered to have poor absorption even if the kidney function was low.

One of the main objections to the use of xylose in absorption studies on pernicious anemia patients was that it was probably of a much smaller molecular size than the active principle of the liver. Xylose has a molecular weight of 150 , while it has been estimated by Dakin, Ungley, and West (13) that the molecular weight of the active principle in liver is slightly less than 5,000 . However, at the present time, we do not know of a material having the desirable properties of xylose which also has a molecular weight similar to that of the active principle. We are therefore reporting our results on our findings as to the absorption of xylose in patients who have pernicious anemia and in three patients having similar blood pictures. Many of the patients studied have been followed by this department for a sufficient length of time for us to know their status as to maintenance dosage of liver extract.

\section{METHODS}

The pernicious anemia patients tested have been followed by this department for varying periods of time up to nine years. The patients classified as to maintenance dosage of liver extract have been followed for at least 18 months. The majority, however, have been followed for a much longer period. The patients able to maintain normal red blood cell counts while taking 3 vials of liver extract or 12 capsules of "Extralin" (Liver-Stomach Concentrate, Lilly) or less were considered as easy to maintain. Those requiring liver extract by injection were classified as difficult to maintain. The normal individuals tested were young healthy adults. None of the patients had diarrhea at the time of examination.

On the day of the test the subject's breakfast was limited to dry toast and one cup of coffee. Approximately 1 hour after breakfast they ingested 25 grams of xylose dissolved in water to which lemon juice had been added to mask the unpleasant taste of the xylose. Twenty-five grams of xylose were used as it was found that 50 grams often produced a diarrhea which might interfere with absorption. The xylose in the 5 succeeding hourly urine specimens was determined by the method described by West and Peterson (14) in which the non-sugar reducing material was removed by a $\mathrm{H}_{2} \mathrm{SO}_{4}-\mathrm{BaCO}_{3}$ precipitation and the reducing sugars determined by the Shaffer-Somogyi (15) reagent after treatment with a yeast suspension. A standard curve prepared with known amounts of xylose was used to convert the titration figures to xylose.

The xylose in the blood was determined by the Shaffer-Somogyi (15) method on filtrates prepared by zinc hydrochloride precipitation (Somogyi (16)). The fermentable sugars were removed by a yeast suspension as before. Van Slyke's (17) method was used for the urea clearance determinations.

\section{RESULTS}

The 8 normal individuals in 5 hours excreted an average of 4.68 grams ( 4.26 to 5.33 grams)

TABLE I

Laboratory and clinical findings in 48 patients with pernicious anemia and in 3 patients with blood pictures of pernicious anemia with free hydrochloric acid in gastric contents

\begin{tabular}{|c|c|c|c|c|c|c|c|c|}
\hline $\begin{array}{c}\text { Case } \\
\text { num- } \\
\text { ber }\end{array}$ & Age & $\begin{array}{c}\text { Red } \\
\text { blood } \\
\text { cells }\end{array}$ & $\begin{array}{l}\text { Hem- } \\
\text { oglo- } \\
\text { bin }\end{array}$ & $\begin{array}{c}\text { Xylose } \\
\text { ex- } \\
\text { creted } \\
\text { in } 5 \\
\text { hours }\end{array}$ & $\begin{array}{l}\text { Urea } \\
\text { clear- } \\
\text { ance }\end{array}$ & $\begin{array}{l}\text { Involve- } \\
\text { ment of } \\
\text { central } \\
\text { nervous } \\
\text { system }\end{array}$ & $\begin{array}{l}\text { Compli- } \\
\text { cations }\end{array}$ & $\begin{array}{c}\text { Main- } \\
\text { te- } \\
\text { nance }\end{array}$ \\
\hline \multirow{9}{*}{$\begin{array}{l}1 \\
2 \\
3 \\
4 \\
5 \\
6 \\
7 \\
8\end{array}$} & years & $\begin{array}{l}\text { mil- } \\
\text { lions }\end{array}$ & $\begin{array}{l}\text { per } \\
\text { cent }\end{array}$ & grams & $\begin{array}{l}\text { per cent } \\
\text { normal }\end{array}$ & \multirow[b]{2}{*}{-} & \multirow[b]{2}{*}{+} & \multirow[b]{2}{*}{ D† } \\
\hline & 60 & 4.7 & 97 & $5.29 *$ & $69^{*}$ & & & \\
\hline & 67 & 5.46 & 101 & $3.19 *$ & 82 & $+t$ & - & D \\
\hline & 45 & 4.64 & 107 & $4.71 *$ & 129* & - & - & D \\
\hline & 40 & 5.45 & 94 & 5.08 & 129 & - & + & D \\
\hline & 31 & 4.73 & 72 & 5.76 & 77 & - & + & D \\
\hline & 67 & 5.01 & 101 & 2.94 & 76 & $t$ & & D \\
\hline & $\begin{array}{l}68 \\
52\end{array}$ & $\begin{array}{l}4.72 \\
4.54\end{array}$ & $\begin{array}{l}97 \\
07\end{array}$ & $\begin{array}{l}3.13 \\
352\end{array}$ & $\begin{array}{l}32 \\
36\end{array}$ & & ++ & $\begin{array}{l}\mathrm{D} \\
\mathrm{D}\end{array}$ \\
\hline & 52 & 4.13 & 92 & 3.42 & $44^{*}$ & - & $+i$ & D \\
\hline 9 & 61 & 5.57 & 129 & $5.34 *$ & $84^{*}$ & - & + & $\mathrm{E} \ddagger$ \\
\hline 10 & 69 & 5.45 & 105 & 4.16 & 55 & $+t$ & + & $\mathrm{E}$ \\
\hline 11 & 59 & 4.91 & $\begin{array}{r}78 \\
101\end{array}$ & 5.80 & 95 & & - & E \\
\hline 12 & $\begin{array}{l}04 \\
64\end{array}$ & $\begin{array}{l}5.40 \\
3.06\end{array}$ & $\begin{array}{r}191 \\
74\end{array}$ & $\begin{array}{l}7.02 \\
5.68\end{array}$ & 77 & - & $\overline{-}$ & D \\
\hline & 65 & 2.03 & 51 & 5.64 & 115 & - & - & D \\
\hline 13 & 72 & 5.81 & 97 & $2.65^{*}$ & $66^{*}$ & + & + & $\mathbf{E}$ \\
\hline 14 & 41 & 5.45 & 111 & $6.68 *$ & $156^{*}$ & - & - & E \\
\hline 15 & $\begin{array}{l}43 \\
50\end{array}$ & 5.40 & $\begin{array}{r}97 \\
107\end{array}$ & $\begin{array}{l}6.42 \\
3.10\end{array}$ & $\begin{array}{l}72^{*} \\
85\end{array}$ & - & $\bar{z}$ & $\underset{\mathbf{E}}{\mathrm{E}}$ \\
\hline $\begin{array}{l}10 \\
17\end{array}$ & $\begin{array}{l}59 \\
57\end{array}$ & $\begin{array}{l}4.04 \\
4.79\end{array}$ & $\begin{array}{l}107 \\
103\end{array}$ & $2.71 *$ & $59 *$ & - & - & $\mathbf{E}$ \\
\hline 18 & 47 & 4.56 & 103 & 5.96 & 120 & - & - & $\overline{\mathbf{E}}$ \\
\hline 19 & 63 & 4.74 & 106 & 5.11 & $108^{*}$ & $+t+$ & - & $\mathbf{E}$ \\
\hline 20 & 62 & 6.00 & 113 & 6.23 & 94 & - & + & E \\
\hline 21 & $\begin{array}{l}36 \\
35\end{array}$ & $\begin{array}{l}5.00 \\
3.26\end{array}$ & $\begin{array}{l}86 \\
84\end{array}$ & $\begin{array}{l}2.98^{*} \\
2.93\end{array}$ & $\begin{array}{l}45^{*} \\
46\end{array}$ & & + & $\begin{array}{l}\text { D } \\
\text { D }\end{array}$ \\
\hline 22 & & 5.41 & 113 & 2.94 & 70 & & + & D \\
\hline 23 & $\begin{array}{l}50 \\
67\end{array}$ & $\begin{array}{l}2.19 \\
4.58\end{array}$ & $\begin{array}{l}03 \\
94\end{array}$ & 286 & $\begin{array}{l}60 \\
52\end{array}$ & & i & D \\
\hline & 6 & 2.9 & 79 & 2.52 & 51 & & + & $\overline{\mathrm{D}}$ \\
\hline 24 & & 5.2 & 120 & 5.69 & 105 & - & . & $E$ \\
\hline & & & & & & - & - & $\mathbf{E}$ \\
\hline
\end{tabular}

* Average of two tests.

$\dagger \mathrm{D}=$ difficult to maintain normal red blood cell counti.e. require liver extract by injection.

$\ddagger E=$ easy to maintain normal red blood cell count on oral liver. 
TABLE I-Continued

\begin{tabular}{|c|c|c|c|c|c|c|c|c|}
\hline $\begin{array}{c}\text { Case } \\
\text { num- } \\
\text { ber }\end{array}$ & Age & $\begin{array}{l}\text { Red } \\
\text { blood } \\
\text { cells }\end{array}$ & $\begin{array}{c}\text { Hem- } \\
\text { oglo- } \\
\text { bin }\end{array}$ & $\begin{array}{c}\text { Xylose } \\
\text { ex- } \\
\text { creted } \\
\text { in 5 } \\
\text { hours }\end{array}$ & $\begin{array}{l}\text { Urea } \\
\text { clear- } \\
\text { ance }\end{array}$ & $\begin{array}{l}\text { Involve- } \\
\text { ment of } \\
\text { central } \\
\text { nervous } \\
\text { system }\end{array}$ & $\begin{array}{l}\text { Compli- } \\
\text { cations }\end{array}$ & $\begin{array}{c}\text { Main- } \\
\text { te- } \\
\text { nance }\end{array}$ \\
\hline & years & $\begin{array}{l}\text { mil- } \\
\text { lions }\end{array}$ & $\begin{array}{l}\text { per } \\
\text { cent }\end{array}$ & grams & $\begin{array}{l}\text { per cent } \\
\text { normal }\end{array}$ & & & \\
\hline 25 & 58 & 5.12 & 103 & 3.83 & 105 & - & - & E \\
\hline & 58 & 2.19 & 59 & 3.27 & 49 & - & - & $\mathrm{E}$ \\
\hline 26 & 51 & 4.59 & 86 & 3.14 & 97 & - & + & D \\
\hline & 50 & 4.22 & 67 & 2.73 & 72 & - & + & D \\
\hline $\begin{array}{l}27 \\
28\end{array}$ & $\begin{array}{l}57 \\
82\end{array}$ & $\begin{array}{l}4.4 \\
5.03 \\
3.82\end{array}$ & $\begin{array}{r}107 \\
81 \\
75\end{array}$ & $\begin{array}{l}4.69 \\
2.00 \\
1.69\end{array}$ & $\begin{array}{l}75 \\
42^{*} \\
29^{*}\end{array}$ & - & ++ & $\underset{\mathrm{E}}{\mathrm{D}}$ \\
\hline 29 & 63 & 4.46 & 94 & 7.82 & 70 & & $+t$ & $?$ \\
\hline 30 & 63 & 3.64 & 82 & 5.41 & 65 & & & D \\
\hline $\begin{array}{l}31 \\
32\end{array}$ & 66 & $\begin{array}{l}3.42 \\
3.72\end{array}$ & 75 & $\begin{array}{l}1.52 \\
357\end{array}$ & $\begin{array}{l}33 \\
80\end{array}$ & & $++t$ & D \\
\hline 33 & 60 & 4.11 & 88 & 5.40 & 59 & - & - & D \\
\hline 34 & 63 & 2.85 & 76 & 4.08 & 60 & & - & $E$ \\
\hline 35 & 64 & $\begin{array}{l}3.83 \\
1.91\end{array}$ & $\begin{array}{l}77 \\
53\end{array}$ & $\begin{array}{r}3.79 \\
270\end{array}$ & $\begin{array}{l}83 \\
54\end{array}$ & & \pm & D \\
\hline 36 & X & 3.31 & 66 & 2.97 & 63 & & $\dot{t}$ & ? \\
\hline 37 & 57 & 3.30 & 64 & 4.22 & 68 & & - & $?$ \\
\hline & 57 & 1.06 & 31 & 3.57 & 41 & 7 & - & $?$ \\
\hline 38 & $\begin{array}{l}40 \\
42\end{array}$ & $\begin{array}{l}2.25 \\
3.97\end{array}$ & $\begin{array}{l}57 \\
84\end{array}$ & $\begin{array}{l}7.78 \\
2.55\end{array}$ & $\begin{array}{r}110 \\
79\end{array}$ & - & $\overline{-}$ & D \\
\hline 39 & 62 & 1.64 & 44 & 3.54 & 39 & $++t$ & + & D \\
\hline & 62 & 2.80 & 79 & 2.70 & 44 & + & + & D \\
\hline 40 & 58 & 1.52 & 44 & 3.53 & 75 & & ++ & $?$ \\
\hline $\begin{array}{l}41 \\
42\end{array}$ & $\begin{array}{l}41 \\
72\end{array}$ & $\begin{array}{l}1.87 \\
2.10\end{array}$ & $\begin{array}{l}46 \\
64\end{array}$ & $\begin{array}{l}3.29 \\
2.94\end{array}$ & $\begin{array}{l}58 \\
39\end{array}$ & + & $\bar{t}$ & $?$ \\
\hline 43 & 67 & 2.12 & 66 & 4.40 & 84 & + & + & $?$ \\
\hline 44 & 64 & 2.62 & 87 & 3.89 & 89 & - & - & D \\
\hline 45 & 51 & 2.36 & 75 & 3.41 & 51 & + & - & $?$ \\
\hline 46 & 64 & 2.41 & 70 & 4.30 & $\begin{array}{l}57 \\
50\end{array}$ & + & - & D \\
\hline & 64 & 4.72 & 97 & 4.49 & 50 & + & - & D \\
\hline 47 & 61 & 2.12 & 59 & $\begin{array}{l}3.77 \\
1.10\end{array}$ & $\begin{array}{r}89 \\
12 ?\end{array}$ & \pm & $\overline{+}$ & $\underset{F}{E}$ \\
\hline $\begin{array}{l}48 \\
49\end{array}$ & $\begin{array}{l}51 \\
56\end{array}$ & $\begin{array}{l}5.27 \\
5.40\end{array}$ & $\begin{array}{l}109 \\
107\end{array}$ & $\begin{array}{l}4.19 \\
2.56\end{array}$ & $\begin{array}{l}123 \\
127\end{array}$ & - & + & D \\
\hline 50 & 30 & 4.79 & 96 & 1.74 & 72 & - & - & D \\
\hline & 7 & 4.34 & 92 & 1.65 & 129 & - & - & D \\
\hline 51 & 72 & 1.24 & 28 & 1.18 & 28 & ++ & ++ & D \\
\hline
\end{tabular}

of xylose. The average of the urea clearances of these individuals was 115.2 per cent. These xylose excretions are slightly lower than those reported by Dominguez and Pomerene (18) whose 3 normal individuals who received 25 grams of xylose excreted from 4.86 to 7.66 grams in 5 hours. Higher results, however, might be expected from the methods used by them.

The average excretion during the 71 examinations on 48 patients having pernicious anemia was 4.28 grams. The average urea clearance, however, was only 78 per cent.

In addition to the patients typical of pernicious anemia, 3 other patients (Cases 49, 50, and 51) were examined. Before treatment, these patients had blood pictures similar to those seen in pernicious anemia, but had hydrochloric acid in their gastric contents. Two of these patients can be classified as having non-tropical sprue. They both require liver extract by injection to maintain a normal red blood cell count. In both of these the urea clearances were normal but the secretion of xylose was markedly decreased. Case 49, with urea clearance of 127 per cent, excreted only 2.56 grams while Case 50 excreted 1.74 and 1.65 grams during two separate 5 hour periods when his urea clearances were 72 and 129 per cent of normal, respectively. Examination of Figure 1, Case 50, shows that there was only a very slight rise in blood xylose during the second test. It is obvious that in these two patients there was a decreased absorption of xylose. Case 51 also requires liver extract by injection. This patient excreted the least xylose in the series, yet there was little xylose in the blood after 5 hours, although the urea clearance was only 28 per cent of normal. The findings in these patients who, without doubt, have disturbances of absorption seemed to indicate that the simultaneous determination of blood and urine xylose following xylose ingestion together with measurements of urea clearance offers a method of measuring absorption from the gastro-intestinal tract.

TABLE II

Average excretion of xylose in pernicious anemia patients grouped as to their urea clearance

\begin{tabular}{|c|c|c|c|c|c|}
\hline Urea clearance & $\begin{array}{c}\text { Num- } \\
\text { ber of } \\
\text { pa- } \\
\text { tients }\end{array}$ & $\begin{array}{l}\text { Num- } \\
\text { ber of } \\
\text { exami- } \\
\text { nations }\end{array}$ & $\begin{array}{l}\text { Aver- } \\
\text { age } \\
\text { xylose } \\
\text { excre- } \\
\text { tion } 5 \\
\text { hours }\end{array}$ & $\begin{array}{l}\text { Below } \\
4.26 \\
\text { grams }\end{array}$ & $\begin{array}{c}\text { Over } \\
4.26 \\
\text { grams }\end{array}$ \\
\hline $\begin{array}{l}\text { Below } 50 \text { per cent of normal... } \\
50 \text { to } 69 \text { per cent of normal.... } \\
70 \text { to } 89 \text { per cent of normal.... } \\
90 \text { to } 173 \text { per cent of normal... } \\
70 \text { to } 173 \text { per cent of normal... } \\
\text { Under } 70 \text { per cent of normal... }\end{array}$ & $\begin{array}{r}9 \\
15 \\
19 \\
13 \\
28 \\
23\end{array}$ & $\begin{array}{l}14 \\
20 \\
21 \\
15 \\
36 \\
34\end{array}$ & $\begin{array}{c}\text { grams } \\
2.89 \\
\mathbf{3 . 7 7} \\
4.22 \\
5.48 \\
4.72 \\
\mathbf{3 . 3 9}\end{array}$ & $\begin{array}{r}9 \\
11 \\
12 \\
3 \\
12 \\
19\end{array}$ & $\begin{array}{r}0 \\
4 \\
7 \\
10 \\
16 \\
4\end{array}$ \\
\hline
\end{tabular}

Table II shows that the kidney function markedly influenced the amount of xylose excreted. There was a progressive increase in average secretion of xylose with increases in the urea clearance. The 28 patients having urea clearances of 70 per cent or better excreted an average of 4.72 grams of xylose. This is slightly higher than the average for the normals. There was, however, much greater spread in the values than in the normals. In individual cases the xylose excretion did not necessarily parallel the urea clearance. Exami- 


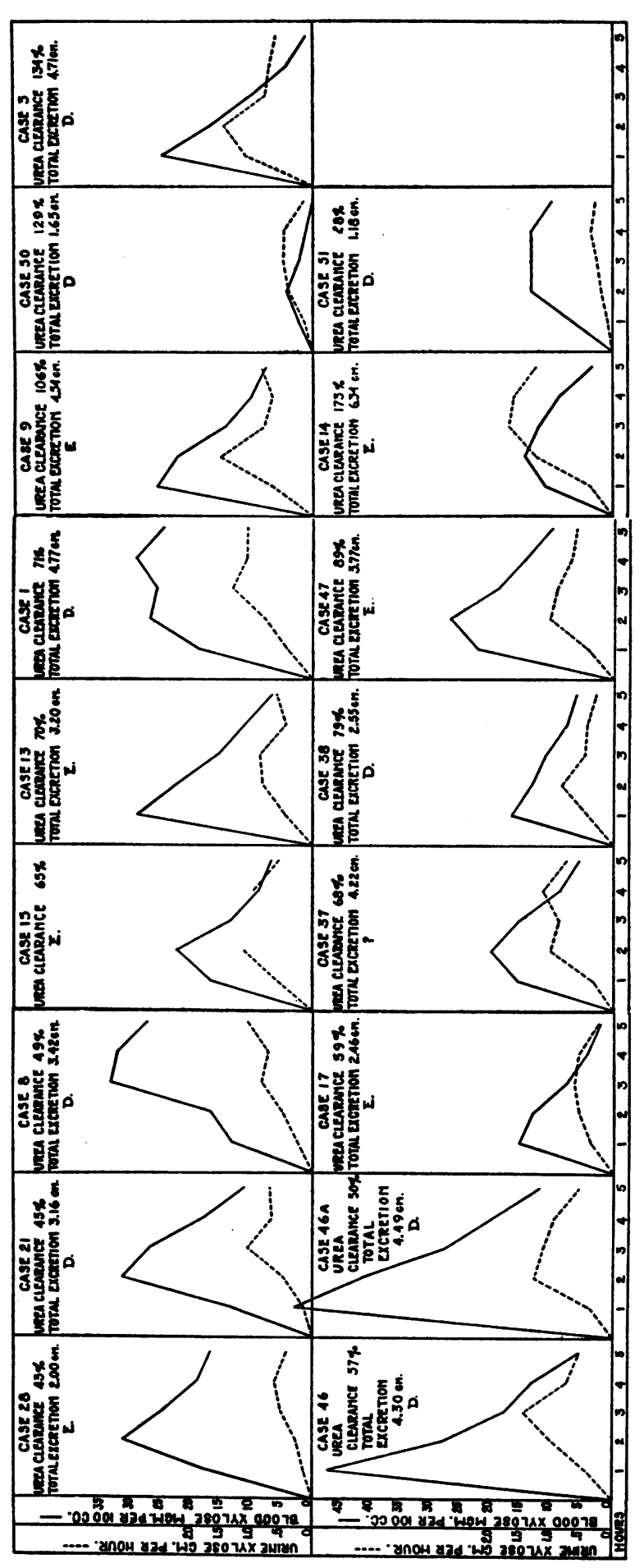

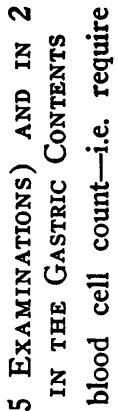

불

卷

近

क

造运

茎点

क 8

帘节

空蛅

z

急

慁导

吕 总

\pm

嵒

ขิ드

总究

果丝

엇 究

$x<\overline{0}$

资是

可

会空

욤

83

ต

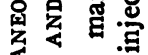

복웅 호

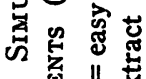

- - 界 项

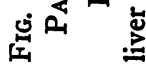


TABLE III

Average excretion of xylose in normal subjects and in various clinical groups of pernicious anemia patients

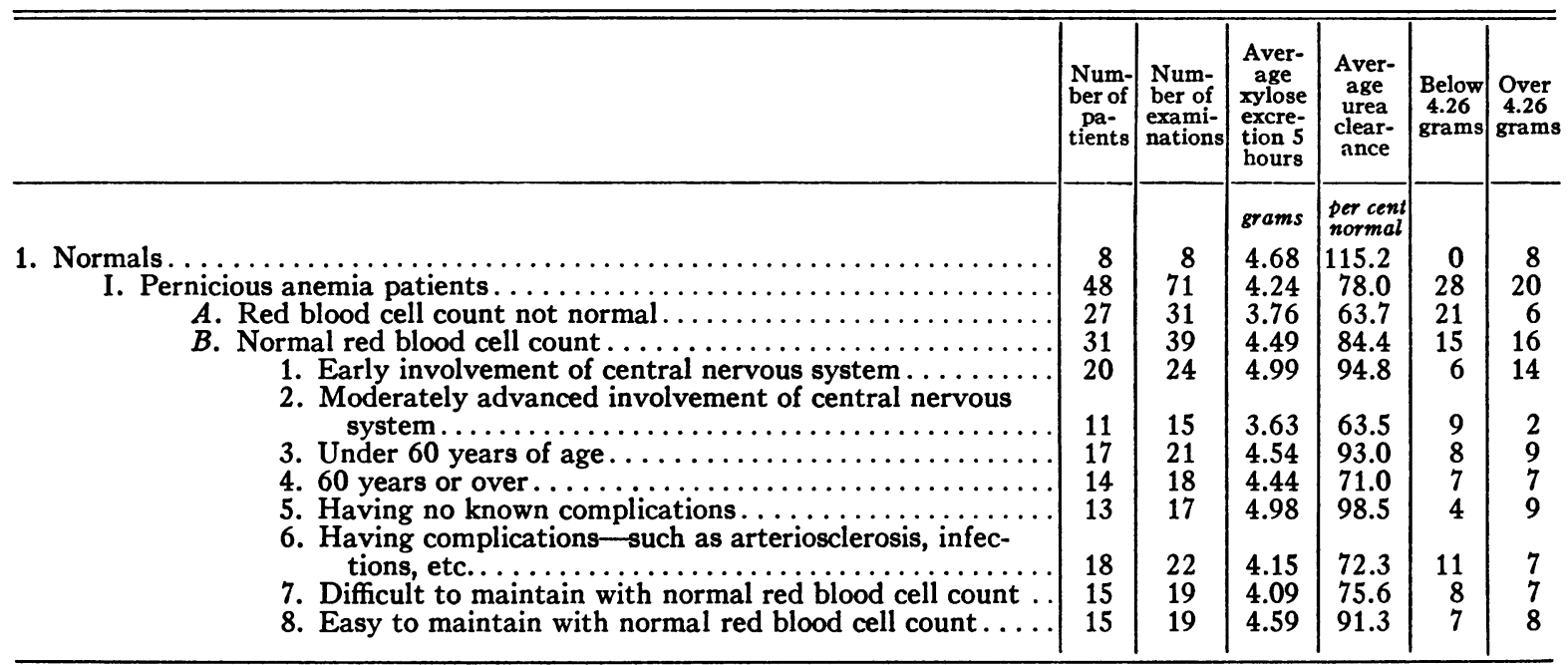

nation of the simultaneous blood and urine curves (Figure 1) yields many interesting data. Cases $13,17,38,50$, and 51 all nearly completely cleared their blood of xylose in 5 hours, yet they excreted markedly decreased amounts of xylose. The fact that the final blood xylose was so low indicates to us that the excretory function of the kidney was not the limiting factor to the small amount of xylose excreted by the kidney. Case 1 , however, excreted 4.77 grams in 5 hours, yet her ability to absorb was such that she still had high blood xylose at the end of 5 hours. The differences in the blood curves and the great variation in the amounts of xylose excreted by Cases $28,21,8$, and $46 \mathrm{a}$, who had only a difference of 7 per cent in urea clearances, likewise demonstrate the importance absorption plays in the excretion of orally administered xylose. The second examination on Case 38 was done during a slight blood relapse which occurred while taking the same amount of parenterally administered liver extract that had previously brought her blood to normal. In this patient there was a drop in urea clearance from 110 to 79 per cent, but this drop cannot account for the marked decrease in excretion of xylose. Thus, it is evident that absorption has a very definite influence on the amount of xylose excreted.

As is shown in Table III, the patients who had normal red blood cell counts were more apt to have higher xylose excretions than those who had red blood cell counts below normal. However, the average urea clearance in the patients having normal red blood cell counts was 84.4 per cent, while the patients not having a normal red blood cell count had an average urea clearance of only 63.7 per cent. In many of the patients there was a marked increase in urea clearance following an induced remission, and this apparently accounts for the greater excretion of xylose in the patients having normal red blood cell counts. Since the low urea clearance on patients in blood relapse is apt to be temporary and since the kidney function so markedly influences the excretion of xylose, only patients having a normal red blood cell count were considered in making the comparisons in Table III.

The average excretion of xylose (see Table III) in patients having more advanced involvement of the central nervous system or advanced arteriosclerosis, infectious or degenerative complications was lower than in those patients not having these complications. However, the lower average excretion may be accounted for by the fact that these patients also had a lower average urea clearance. Of the 15 patients excreting less than 4.26 grams of xylose, only two did not have at least one of these complicating factors, while 7 of the 16 excreting more than 4.26 grams had no known complications. It cannot be said that increase in age in itself was associated with a decrease in excretion of xylose in these patients. 
although there was a progressive decrease in urea clearance with increasing age.

There were 30 patients who had been followed for a sufficient length of time to be considered as to maintenance dosage of liver. As seen in Tables I and III and in Figure 1, there seems to be little if any correlation between the amounts of xylose excreted and the amount of liver extract required to maintain the blood at normal levels. In Cases 2, 6, 22, and 26 (see Table I) it was felt that the small amounts of xylose excreted in urine might indicate that they did not have satisfactory absorption from the gastrointestinal tract and therefore required larger amounts of liver extract. Cases 13,16,17, and 25 , however, did not excrete xylose any better, but they have maintained their blood at normal levels for prolonged periods of time on oral liver therapy. In two of these latter patients (Cases 13 and 17), examination of the simultaneous blood and urine curves shows conclusively that the decreased excretion was limited by the absorption of xylose and not by the excretory ability of the kidneys. Cases 1, 4, 5, 12, 27, and 46, who have had one or more severe relapses while taking potent material by mouth in customary dosage, certainly cannot be said to have any difficulty in absorbing xylose from the gastro-intestinal tract.

\section{SUMMARY}

The results of these studies indicate that absorption from the gastro-intestinal tract greatly influences the amount of orally administered xylose excreted in the urine during the first 5 hours after its ingestion. Thus it would appear that study of the urinary and blood xylose following its oral administration yields considerable information as to the absorptive ability of the gastrointestinal tract. If the kidney function is normal as shown by the urea clearance test and the excretion of xylose is low, it can be assumed that absorption of xylose from the gastro-intestinal tract is poor. This assumption is justified since it has been shown that xylose is not metabolized, passes through the liver unchanged, and can be recovered from the urine. Even in patients having lowered kidney function, information may be gained as to their ability to absorb xylose from the gastro-intestinal tract if, in addition to deter- mining the xylose in urine, blood xylose curves are made. It has been shown that the xylose disappears from the blood stream at a rate proportional to the actual momentary concentration of the nonfermentable reducing substances in the blood and that there is a retention of xylose in the blood if kidney function is poor. Therefore, if the kidney function is decreased and the blood xylose does not rise as expected and is not retained in blood at $\mathbf{5}$ hours, it would appear that the decreased xylose excretion is due in part, at least, to a decrease in absorption from the gastrointestinal tract.

In these studies we were unable to demonstrate any constant abnormality in absorption of xylose in pernicious anemia patients. The average excretion of the pernicious anemia patients having normal urea clearance was slightly higher than that of the normal individuals. There was no correlation between the amounts of xylose absorbed by patients having pernicious anemia and the amounts of orally administered liver extract required to maintain the patients with normal blood counts. The 2 patients clinically diagnosed as non-tropical sprue and another patient having free acid in the gastric juice but having a blood picture of pernicious anemia had markedly decreased absorption of xylose from the gastrointestinal tract in the absence of diarrhea. All three of these patients require liver extract by injection to maintain a normal red blood cell count.

Since there may be a marked difference in the molecular size of xylose and that of the active principle of the liver, it does not necessarily follow that patients able to absorb xylose will absorb the active principle satisfactorily. We believe, however, that the results obtained from these studies indicate that differences in absorption from the gastro-intestinal tract can be demonstrated in pernicious anemia patients, although these differences seem to have little or no relationship to the amount of orally administered liver extract required by the patient to maintain a normal red blood cell count.

\section{CONCLUSIONS}

No consistent abnormality in absorption of $x y-$ lose from the gastro-intestinal tract could be demonstrated in patients having pernicious anemia. 


\section{BIBLIOGRAPHY}

1. Beebe, R. T., and Lewis, G. E., The maintenance dose of potent material in pernicious anemia. Am. J. M. Sc., 1931, 181, 796.

2. Fouts, P. J., and Zerfas, L. G., Maintenance dosage of liver extract in the treatment of pernicious anemia. Ann. Int. Med., 1933, 6, 1298.

3. Gänsslen, M., Ein hochwirksamer, injizierbarer leberextrakt. Klin. Wchnschr., 1930, 9, 2099.

4. Castle, W. B., and Taylor, F. H. L., Intravenous use of extract of liver. J. A. M. A., 1931, 96, 1198.

5. Heath, Clark W., and Fullerton, H. W., The rate of absorption of iodide and glycine from the gastrointestinal tract in normal persons and in disease conditions. J. Clin. Invest., 1935, 14, 475.

6. Corley, R. C., Pentose metabolism. I. The disposal of intravenously administered xylose in the rabbit. J. Biol. Chem., 1926, 70, 521.

Corley, R. C., Pentose metabolism. II. Factors affecting the disposal of $l$-arabinose and $d$-xylose in the rabbit. J. Biol. Chem., 1928, 76, 23.

7. Fishberg, E. H., and Friedfeld, L., The excretion of xylose as an index of damaged renal function. J. Clin. Invest., 1932, 11, 501.

8. Jolliffe, N., The excretion of xylose by glomerular and aglomerular kidneys. Proc. Soc. Exper. Biol. and Med., 1930, 28, 5.

Chasis, H., Jolliffe, N., and Smith, H. W., The action of phlorizin on the excretion of glucose, xylose, sucrose, creatinine and urea by man. J. Clin. Invest., 1933, 12, 1083.
9. Jolliffe, N., Shannon, J. A., and Smith, H. W., The excretion of urine in the dog. III. The use of non-metabolized sugars in the measurement of the glomerular filtrate. Am. J. Physiol., 1932, 100, 301.

10. Keith, N. M., Power, M. H., and Peterson, R. D., Renal excretion of xylose after intravenous injection in man. Proc. Staff Meet., Mayo Clin., 1934, 9, 43.

11. Fishberg, E. H., The rate of disappearance of foreign sugar from the blood stream. J. Biol. Chem., 1930, 86, 665.

12. Fishberg, E. H., and Friedfeld, L., Excretion of xylose as a measure of renal function in children. Am. J. Dis. Child., 1933, 45, 271.

13. Dakin, H. D., Ungley, C. C., and West, R., Further observations on the chemical nature of a hematopoietic substance occurring in liver. J. Biol. Chem., 1936, 115, 771.

14. West, E. S., and Peterson, V. L., The sugars of urine. I. Determination of the reducing sugars of urine. Biochem. J., 1932, 26, 1720.

15. Shaffer, P. A., and Somogyi, M., Copper-iodometric reagents for sugar determination. J. Biol. Chem., 1933, 100, 695.

16. Somogyi, M., A method for the preparation of blood filtrates for the determination of sugar. J. Biol. Chem., 1930, 86, 655.

17. Peters, J. P., and Van Slyke, D. D., Quantitative Clinical Chemistry. Volume II. Methods, Williams and Wilkins Co., Baltimore, 1932, p. 564.

18. Dominguez, R., and Pomerene, E., On the renal excretion of xylose. J. Clin. Invest., 1934, 13, 753. 